IRSH 65 (2020), pp. I0I-I08 doi:I0.1017/S0020859020000036

(C) 2020 Internationaal Instituut voor Sociale Geschiedenis

\title{
Poor Relief, Welfare, and Community Building
}

\author{
KATHERINE A. LYNCH \\ Department of History \\ Baker Hall 240, Carnegie Mellon University \\ 5000 Forbes Avenue, Pittsburgh, PA I5213-3890, USA \\ E-mail: KLI8@andrew.cmu.edu
}

\begin{abstract}
AвSTRACT: This review introduces the broad themes and methods of Maarten Prak's Citizens without Nations and focuses on the author's portrait of actual practices of citizenship in early modern cities of Europe. It highlights the strengths of Prak's study in formidable archival work and broad comparative reading. It points out the central place of practices of poor relief to the building of urban networks of citizenship, drawing out the importance of women in participating in these informal yet critical practices of citizenship. Taking the relationship between provisioning for the poor and community building seriously, and building on Prak's view of Britain's relatively smooth transition from early modern to modern practices of citizenship, the essay speculates on whether England's unusual nationwide poor law (born in the early modern period and exemplifying ideals of citizenship usually associated with "urban republicanism") played its own critical role in the rise of an integrated nation there.
\end{abstract}

\section{INTRODUCTION}

Maarten Prak's Citizens without Nations: Urban Citizenship in Europe and the World, $1000-1789$ is a major contribution to urban history and to the understanding of what the author sees as the principal institutions and belief systems that Europeans used to practice citizenship in the early modern period. He further explores how these experiences of citizenship affected later processes of nation building. It is a revisionist work of immense erudition, based upon the author's well-known archival research - mainly on the Dutch Republic - but also on extensive reading in comparative historiography, political science, and economics. The seventy-page bibliography evidences the depth and range of the foundations underlying the work. As announced in the title, Prak sets his book in the longue 
durée of European history, privileging Western Europe, where urban citizenship flourished, albeit to various degrees and in different forms according to specific time and place.

This is a book of big comparisons and ambitious arguments. In that sense, as Prak acknowledges, it recalls the historical-comparative work of Charles Tilly, Barrington Moore, or Theda Skocpol, who asked questions that required broad-based and interdisciplinary research to answer. Here, the author looks for patterns across time including how urban practices of citizenship passed into the post- 1789 world, querying how and whether urban interests were effectively integrated into nation-state organizations of which cities were a part. While the questions the book asks and the comparisons themselves are broad and sometimes theoretical, Prak also earns his stripes as a careful historian who has spent a lot of time in the archives, supplying a wealth of empirical evidence to illustrate his arguments. Like Tilly, Prak emphasizes mid-level comparisons among regions over decades or hundreds of years. He explicitly rejects long-term path-dependency models, such as the one that led Robert Putnam to hypothesize long-term continuities in the degree of civic engagement in different regions of Italy. ${ }^{1}$

In the discussion of the book in our session at the 2018 meeting of the Social Science History Association, other contributors focused on the usefulness of the notion of citizenship outside Europe and on Prak's examination of whether urban citizenship helped to foster capitalism in the West. On the latter topic, I will limit myself to several points. First, Prak is skeptical of a direct causal relationship between ideals and practices of citizenship in the early modern world and the growth of capitalism. Instead, throughout the book, Prak emphasizes the importance of what Heinz Schilling termed "urban republicanism", 2 a widely shared model of citizenship in the early modern age that usually protected the economic rights and prerogatives of citizens, thereby hampering the breakdown of restrictions on unfettered capitalist practice. On the other hand, the author argues that the successful integration of emerging urban capitalist ideals in the United Kingdom did help usher in the era of industrial capitalism. ${ }^{3}$

In my contribution, I first discuss the broad features of the book, its approach, and its major arguments. After this, and given my own interests and expertise, I will focus on Part I, with some comment on Part II and the Conclusion as well.

I. Maarten Prak, Citizens without Nations: Urban Citizenship in Europe and the World, I000I789 (Cambridge, 2018), p. I 82.

2. Ibid., p. 43.

3. Ibid., p. 225 . 


\section{MAJOR ARGUMENTS AND APPROACHES}

Prak lays out the key arguments of his book in several places. He states: "[...] I hope to demonstrate that, compared to the practices of nineteenth-century national citizenship, premodern urban citizenship actually has quite an impressive track record when it comes to political freedom, social equality and inclusiveness; or, to phrase it in the terms of 1789 , of liberté, égalité, fraternité". ${ }^{4} \mathrm{He}$ illustrates this by using the book to show how urbanites actually practiced citizenship. He writes: "Citizenship [...] is not so much concerned with distinctions between categories of people, but rather with the roles people play in society". Moreover, "[d]efining citizenship as a set of practices [...] implies that citizens themselves can shape and [...] create their own citizenship [...] but that they do so only as part of a collective. The development of citizenship therefore needs to be explained as a form of collective action". ${ }^{6}$

Seeking to cut through what he sees as excessive scholarly focus on the French Revolution as the best window on understanding European citizenship, Prak goes beyond an inquiry limited to studying the formal status of citizen and engages more with actual evidence of "citizen engagement". Borrowing from Max Weber's own distinction on the topic of rationality, I would say that Maarten Prak's book studies not merely formal, but also substantive citizenship. The author is keenly interested in "effective" citizenship and believes that the most recent evidence from early modern cities can revise our view of it. Indeed, he argues that early modern urban citizenship, with its face-to-face realities, may prove instructive in a world of nation states where citizens seem to feel increasingly estranged from their faraway and "imagined" communities. A better understanding of the strengths of early modern citizenship, Prak argues, can provide models for re-infusing a real sense of membership among today's citizens.

The work is divided into three parts: Part I, on European Towns, includes chapters on "Formal Citizenship", "Urban Governance: Citizens and their Authorities", "Economic Citizenship through the Guilds", "Welfare and the Civic Community", and "Citizenship, Soldiers, and Civic Militias". Part II traces the development of urban citizenship in Italy, the Netherlands, England, and "Continental Europe". In Part III, Prak stretches his comparative analysis to China, the Middle East, and the Americas.

\section{THE EXPERIENCES OF URBAN CITIZENSHIP}

In Part I, Prak presents data on the extent of urban citizenship for cities that have been studied in sufficient detail, some of them by Prak himself, to 
show that, in many places, a majority of household heads enjoyed the formal status of citizen, a departure from views that have seen this status as limited (unlike modern national citizenship) to a small elite. He traces ways that migrants could achieve citizen status, recalling the vital demographic fact that most, if not all early modern towns or cities required influxes of migrants to mitigate high mortality rates that threatened to deplete their populations. ${ }^{7}$ Becoming a citizen was not always easy, however, and indeed many who migrated in were also required to migrate out when the demand for labor had waned or political exigencies demanded it. Yet, the process of obtaining full membership in the urban community was possible for men who brought scarce skills or capital to the table. Prak finds no national-level regularities in the extensiveness of urban citizenship status.

Turning to citizenship politics, Prak argues for the widespread similarities in ways that urbanites felt themselves legitimately entitled to pursue the representation of their interests among urban governments using a variety of tools such as petitions, pamphlets, or "instructions for public officials". He notes: "Because urban republicanism was a practical, rather than a theoretical philosophy, its discourse is found primarily in the sort of papers produced by urban institutions and citizens themselves [...]". ${ }^{8}$ This and other reflections spread throughout the text remind us of Prak's long career in the archives. On the critical topic of inequality, Prak addresses the elite composition of organizations such as Common Councils and the self-perpetuation of governing elites. Yet, he seeks to revise our view of actual practices of citizenship by showing the typical access that men of the middling ranks had to more broadly representative institutions such as those in neighborhoods or guilds of early modern cities. Prak anticipates the criticism of readers who would focus on the huge social distance that could separate urban citizens from their governors and thereby radically distinguish pre-modern from modern governance. His response to his anticipated critics reflects his skepticism of arguments that posit a radical difference between pre-modern and modern relations between citizens and those who govern them. He writes: "Such criticism [of the limits of early modern citizenship] implies a peculiar understanding of modern democracy. Clearly, the profile of modern-day politicians is not identical with their electorate in terms of income, education, gender or social background [...] The point about democracy is the mandate that politicians receive from the electorate, not whether they resemble the average voter in all respects".?

Using a wide range of archival material, Prak illustrates his point that citizens experienced their world through concrete collective action, often for

\footnotetext{
7. Ibid., p. 100.

8. Ibid., p. 47.

9. Ibid., p. 68.
} 
the redress of felt grievances. Perhaps controversially for twentieth and twenty-first century scholars, who see a search for equality in nearly all intracity struggles of leaders and followers, Prak mainly sees citizens united in the search for such practical goods as protection, honest government, safety, and, above all, for their voices to be heard and taken into consideration by those who governed them. Prak's portrait of urban conflicts and struggles reflects his fine understanding of the psychology of governance and a relationship between governed and governors entailing mutual obligations, compromise, and the search for "transparency" worked out in a set of ongoing face-toface relationships. He estimates that the effective experience of urban citizenship peaked around I $500 .{ }^{10}$ Prak's portrayal of governance and citizenship as a set of relationships involving these same features reappears at a later point in the text in his discussion of seventeenth and eighteenth-century relationships between the interests of British Crown and City and those between members of Parliament and their constituencies. ${ }^{\text {II }}$

Although Prak's discussion up to this point in the text focuses on men's experiences, his portrait of urban guilds introduces women into the picture where they play a role that exposes some of the less inspiring features of urban republicanism. As already noted, men of the middling and lower ranks could actively participate in citizenship relations in organizations such as guilds, institutions that Prak sees as much more socially diverse than earlier scholarship had led us to believe. As is well-known, guild members frequently tried and often succeeded in using their guild-based citizen privileges to revise membership rules using their model of "urban republicanism". Especially during periods of economic stress or secular economic change, the defense of guild privilege entailed excluding women members, both those who possessed membership entitlements by their own skill and efforts or (if widows) through their husband's status.

\section{PRACTICES OF ASSISTANCE}

The appearance of women in the consideration of guilds and the struggle between women and men for the privileges of urban citizens reminds the reader that up to this point there has been relatively little consideration of gender in the text. Prak remedies this lacuna somewhat in Ch. I. 4, "Welfare and the Civic Community." Here, Prak calls to readers' attention the important question of entitlements to assistance. He writes: "Even though, with very few exceptions, nobody had a legal entitlement to poor relief, all urban communities in Europe provided elaborate welfare arrangements on which the poor in those communities could exercise at least a moral claim". ${ }^{\mathrm{I} 2}$ "Poor

\footnotetext{
Iо. Ibid., p. 80.

I I. Ibid., pp. 21 3-220.

I 2. Ibid., p. I 38 .
} 
relief" in early modern cities seems a more appropriate label for these efforts than "welfare" institutions in Prak's chapter title but neither one is perfect, and Prak's use of "welfare" seems better for drawing out comparisons between assistance in early modern and modern society.

In my own work, I have argued that early modern cities contained two distinctive if complementary kinds of community building efforts that poor relief was meant to serve - civic and religious-confessional - and that were based on members' different legal or moral claims of entitlement. ${ }^{13}$ Through his chapter title, Prak announces that his discussion privileges the "civic" approach to poor relief. He traces the growth of expansive programs by city governments, but notes that these usually occurred in concert with the established church or voluntary confessional organizations such as the large and wealthy confraternities of Italy. Indeed, then as now, religiously-oriented voluntary associations were often granted oversight and management of city poor relief schemes, which usually targeted the respectable, resident poor. While city fathers supported and responded to claims for assistance from citizens, often through values of "civic religion", clergy or religiously inspired lay people, respectively, had the power of the pulpit and appeals to religious ideals to shame the miserly in public if need be.

By emphasizing civic over confessionally based welfare schemes, however, Prak has missed an opportunity to explore the massive importance of lay women and women's religious communities in the provision of relief to the poor, including the "civic" poor. Though they did not enjoy the formal status of citizen, women both lay and religious figured importantly as civic actors through their efforts to organize formal efforts for the relief of the poor, participate in and sometimes lead institutions and, importantly, come face-to-face with the poor in neighborhoods or institutions. I would argue that these experiences served a critical role in building and legitimizing both religious and civic structures of urban authority. As the work of Abram de Swaan so brilliantly argued, systems of assistance did not result from successful communities of citizens but rather were essential to building them. ${ }^{14}$

But what was the "bottom line" in all of these relief efforts? Prak furnishes some interesting statistics that challenge the historically minded reader to meditate on comparisons between early and late modernity. If the "bottom line" of poor relief assistance in the early modern world was modest - at most five per cent of societal wealth - Prak shows that it was not until the second half of the twentieth century that European societies' expenditures on the poor reached levels significantly above this figure. As it was, Prak

I3. Katherine A. Lynch, Individuals, Families, and Communities in Europe, 1200-I800: The Urban Foundations of Western Society (Cambridge, 2003).

I4. Abram de Swaan, In Care of the State: Health Care, Education and Welfare in Europe and the USA in the Modern Era (Cambridge, 1988). 
notes that payments to the resident poor in the early modern world could have raised their income by a fifth to a third. ${ }^{\text {Is }}$

\section{THE IMPLICATIONS OF WELFARE FOR NATION-BUILDING}

It is regrettable that Prak leaves the discussion of civic welfare systems as he turns to Part II, where he explores how early modern experiences of citizenship in different regions figured into the longer history of nation-building. A major question underlying this part of the book is: did apprenticeship in the practices of citizenship in early modern cities help to smooth out the process of building modern nations? The answer seems to be: not so much, at least in most areas of Europe. For Prak, England was most successful in building upon ideals of urban citizenship. Yes, it did take two seventeenth-century revolutions to help bring the nation into being, but there were other contentious if less murderous struggles that the English and then British worked their way through - especially the thorny problem of how to integrate effectively the special interests of cities into an emerging national community. Prak's discussion of the political dimensions of the struggle are detailed and persuasive.

In his story of Britain's emergence as an "imagined community", however, it seems that the author has missed an opportunity to apply his analysis of comparative welfare history to a long-standing question of why the English system of assistance to the poor began to diverge from a more typical continental model in the early modern period. Furthermore, what difference might this have made in the transmission of ideas and practices of civic welfare to nation-building? In England, as is well-known, a poor law funded by mandatory poor rates required of occupiers began to spread through the country during the sixteenth century, with enforcement ensured by local officials who were accountable to the Crown as well as their localities. Episodes of temporary, mandatory city-level poor laws were familiar throughout early modern Europe, as Prak discusses. But these continental poor laws occurred only in emergencies and were soon revoked. The English Poor Law, in contrast, was different in its national reach and apparent enforceability. Admittedly, there was nothing particularly urban about the law's effects since the vast majority of the English poor at the time of its origins were rural dwellers. Yet, the formation and application of the law, along with its notion of entitlements for the respectable, resident poor, seem to have partaken of some of the same ideals of "urban republicanism" that Prak shows were widespread and critical to the practice of European citizenship in the early modern world.

I s. Prak, Citizens without Nations, p. I 37 . 
Drawing on this strand of the book's analysis, one might ask: was the English Poor Law important in shaping England's and then Britain's path to nationhood? Did the creation and enforcement of a national poor law, with its suggestion of the respectable poor's legitimate entitlement to relief contribute to this evolution? How vital were functional systems of assistance for building national communities based on citizenship rights like those studied in the book? Although it was never Maarten Prak's intention to pursue this specific line of analysis, the fact that his study raises these and so many other questions and paths to future research is a testament to the rich complexity of his book.

\section{CONCLUSION}

If there was no one sure path to modern citizenship throughout Europe, Prak has well illuminated its basic constituent elements and called our attention to why it is important that we have a good understanding of citizenship in its early modern settings. Indeed, one of Prak's goals is to advocate that we re-commit to the kind of active citizenship he has anatomized. This would involve such things as the revitalization of local governance and the devolution of power from national and supranational governments, a process that he notes is already underway. In his closing pronouncement, the author returns to the approach that has animated the entire text, emphasizing that " $[\ldots]$ the objective of citizenship is ultimately to create agency for the individual members of society [...]". To this end, Maarten Prak argues: "urban citizenship has a pedigree that is not only worth revisiting; it could [...] be a source of political and social inspiration". ${ }^{16}$ 